\title{
Agroforestry Development Strategy in West Halmahera Regency, North Maluku
}

\author{
Nurhasni Sirajudin ${ }^{1}$, Muhammad Ridwan ${ }^{2}$, Daud Malamassam ${ }^{2}$ \\ ${ }^{1}$ Postgraduate Student of Forestry Science of Postgraduate School, Hasanuddin University \\ ${ }^{2}$ Lecturer of Forestry Science of Postgraduate School, Hasanuddin University
}

\begin{abstract}
The structure of agroforestry management in West Halmahera Regency was mostly managed modestly and the primary constituents were annual plants (Multi-Purpose Tree Species). The study aimed to 1) describe agroforestry patterns and systems, 2) identify and analyze internal and external factors whichwere determinants of agroforestry development attempts, and 3) formulate priority strategies to accelerate agroforestry development. The research was conducted from March to June 2021. The results showed that the agroforestry patterns applied by farmers were Agrisilviculture and Agrosilvopasturemodes. Furthermore, the results of the SWOT analysis showed that the alternative strategies which could be offered were 1) Socialization by relevant parties to encourage the community to enhance forestry plant cultivation, for the sake of soil and water conservation, and also as a business opportunity. In this regard, the community needed to be assisted with quality seeds, in addition to optimizing the use of available seeds on the community's lands; 2) Increasing the intensity of the implementation of guidance, counseling, and assistance, taking into account the conditions and problems faced by farmers in the field; 3) Boosting the intensity of education and training to develop community insights and skills regarding good cropping systems, proper use of pesticides, pest and disease prevention in plants. The three alternative strategies offered are to overcome the weaknesses and deal with the threats experienced shortly agroforestry development efforts.
\end{abstract}

Keywords: agroforestry, Agrisilviculture, Agrosilvopasture, SWOT, AHP

\section{INTRODUCTION}

The alteration of forest land into agricultural land maylead to many problems such as decreased soil fertility, erosion, extinction of flora and fauna, floods, droughts, and even global climate change so that the problems are sustainably predicted to get worse from time to time in line with the increasing area of forest converted to agricultural land used as another business area [1]. In addition, the reconstruction of agricultural land to other businesses also results in the area of agricultural land being reduced or limited in fulfilling the food supply of the community, therefore it can allow the emergence of social problems [2] and reduced land tenure of each household.

Agricultural practices and land use which do not pay attention to the principles of soil and water conservation, lead to the appearance of critical land, erosion, drought, and a decrease in the quality and quantity of agricultural products [4]. Besides, the level of food demand also continues to increase, so technological adoption in agriculture is needed by farmers to be able to utilize the land more optimally.

Agroforestry can be a land management system which can solve social, economic, and ecological problems. The application of the agroforestry system is expected to improve people's income and welfare, provide more job vacancies, boost the number of agricultural productions in the next few years [5], answer the scarcity problems regarding food, wood, energy, and water [6] and overcome environmental problems that arise due to land-use alteration. Hence, agroforestry is a system of optimizing land use by mixing woody plants, crops, livestock, and others on the same land unit to maximize profit.

Nevertheless, the application of agroforestry systems is also often considered less productive because it does not have careful planning, so it cannot support the needs of farmers in the long term, even though the land is 
DOI: $\underline{10.51386 / 25815946 / \mathrm{ijsms}-\mathrm{v} 4 \mathrm{i} 4 \mathrm{p} 112}$

Volume: 4 Issue: 4

July to August 2021

https://www.ijsmsjournal.org

planted with various types of crops [7]. Although the land is planted with many types of crops and they have become a fixed income, it is not able to help and fulfill the daily needs of farmers, so they have to look for other sources of income to meet household needs or work as farm laborers.

In the management of agroforestry, it is hoped that it can benefit all types of constituent plants, both agricultural, forestry, or tree crops, as well as other constituent components. Therefore, for agroforestry as a technology to achieve its objectives, an appropriate strategy is needed that is under the needs in the field. An appropriate strategy will be very effective in supporting the development of agroforestry which can later be applied by farmers and related parties, to increase agricultural productivity [8]. Because the benchmark for the success of agroforestry management can be seen from the amount of farmers' income from agroforestry products or products and can be sustainable and maintain environmental balance. Communities will choose and adopt a technology (agroforestry) if it can provide definite and continuous results (income) either daily, monthly, yearly, or seasonally.

In West Halmahera Regency, the majority patterns of agroforestry management are managed in a conventionalmode andthe main constituents are annual plants (Multi-purpose Tree Species). Most people prefer to plant MPTS or Multi-purpose Tree Species as the main crop because it is considered to have high economic value and has a good ecological function and only a small number of people select to intercrop with seasonal or horticultural crops. MPTS crops are the primary source of income for farmers and have monthly and seasonal yields.

For farmers who have a land area of <1-1 ha, the particular crop which is the fundamental source of farmers' income, most are less able to boost household economic income due to the long next harvest period, and the less optimal use of land under tree stands. In addition, the community's low interest in cultivating forestry plants as the primary crop or intercropping. Therefore, it is necessary to research what strategies can be done to advance the development of agroforestry in West Halmahera Regency, but still by considering the practices of agroforestry patterns carried out by the community. Based on the above problem conditions, the objectives of this study are (1) to describe the agroforestry patterns and systems applied by farmers in West Halmahera Regency, (2) to identify and analyze internal and external factors that are the determinants of agroforestry development efforts, and (3) to formulate priority strategies to accelerate agroforestry development.

\section{METHODOLOGY}

The study was conducted in three villages including Rioribati Village, Tabapeace Village, and Gamsungi Village located in West Halmahera Regency, North Maluku Province between March and June 2021. The data collection employed the method of survey and interviews (questionnaires) on respondents who were determined voluntarily (purposive sampling)comprising 30 respondents from farmers who applied agroforestry and 9 respondents from experts. The data taken are primary data and secondary data. The primary data were collected directly in the field through field observations (surveys) and structured interviews using questionnaires. Primary data sourced from respondents included applied agroforestry patterns and systems as well as internal and external factors that determine the efforts to develop agroforestry in West Halmahera Regency. Meanwhile, secondary data are sourced from agency documents, village government, literature studies, and references relevant to this research problem.

The collected data was then analyzed using descriptive and quantitative analysis as well as SWOT-AHP. Descriptive and quantitative analysis was used to analyze the data on the socio-economic characteristics of the respondents and described the applied agroforestry patterns and systems. The SWOT-AHP analysis was used to formulate strategies and determine alternative strategies using data on internal factors (strengths and weaknesses) and external factors (opportunities and threats).

The stages of research and analysis of SWOT-AHP data were 1) identifying internal factors (strengths and weaknesses) and external factors (opportunities and threats) which were relevant in West Halmahera Regency, 2) 
DOI: $\underline{10.51386 / 25815946 / \mathrm{ijsms}-\mathrm{v} 4 \mathrm{i} 4 \mathrm{p} 112}$

Volume: 4 Issue: 4

July to August 2021

https://www.ijsmsjournal.org

creating a hierarchical structure of SWOT-AHP analysis, 3) making a pairwise comparison matrix to get the weight values in the SWOT group and the SWOT factors which had been identified, by comparing one criterion with another. Opinions of experts should be consistent, namely by calculating the Consistency Ratio (CR). If CR $<0$, it was considered an error, $\mathrm{CR}=0$, it was considered very consistent, $\mathrm{CR}>0-1$, was considered consistent and CR > 1, it was considered inconsistent, 4) formulating an agroforestry development strategy using the SWOT matrix to obtain SO, ST, WO, and WT strategies. Strategy formulation based on the three highest average scores of respondents on each SWOT factor, 5) determining alternative agroforestry development strategies using pairwise comparisons.

The SWOT-AHP hierarchical structure consisted of four levels, with the first level being the objective or focus of the problem to be studied. The second level was broken down into SWOT (Strengths, Weaknesses, Opportunities, and Threats) groups, the third level described the factors associated with each SWOT group. The fourth level was an alternative strategy that could be offered for the development of agroforestry in the West Halmahera Regency at this time [9]. The SWOT-AHP hierarchical structure can be seen in Figure 1.

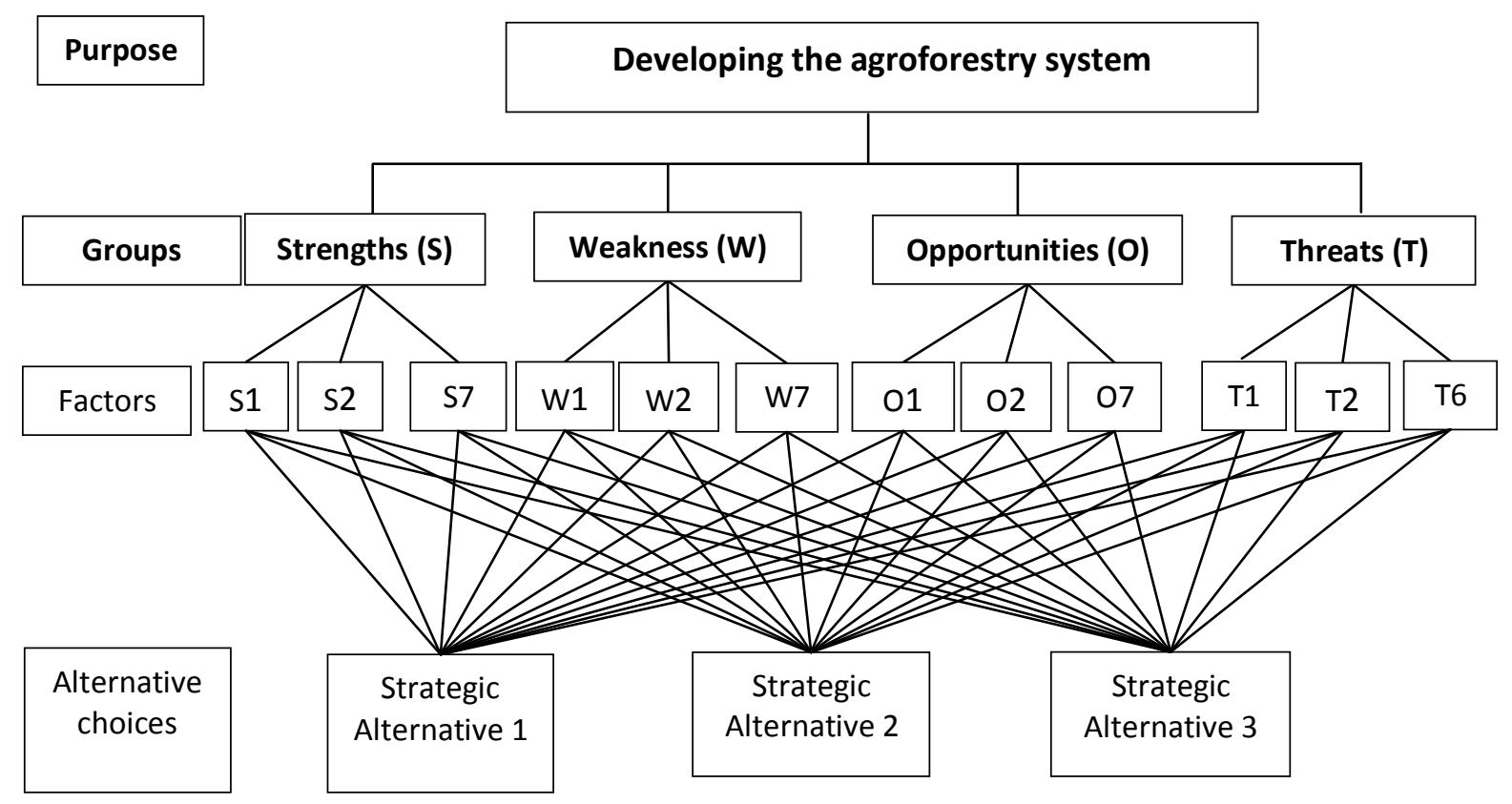

Figure 1. SWOT-AHP Hierarchy Chart

III. RESULTS

AND DISCUSSION

\section{A. Agroforestry Patterns and Systems in West Halmahera Regency}

The type of agroforestry implemented in the West Halmahera Regency includes traditional agroforestry which is managed in the form of mixed plantations. There are two forms of agroforestry which are applied in common, namely Agrisilviculture and Agrosilvopasture. The form of Agrisilviculture applied is to combine several types of tree crops (forestry), MPTS plants, bamboo, monthly plants on the same land. Forestry plants are planted as land boundaries either around the land or only as garden boundary markers, some are planted in the middle of the land or grow naturally and are cared for together with other plants, and on the banks of rivers to prevent landslides. In line with research [10] that there are two spatial arrangements in the form of Agrisilviculture applied by the community in East Halmahera, namely the fence and random forms. Based on the results of the research, some plant forestry plants and MPTS plants are separately (a division of space) in the same land management unit because forestry plants can affect the productivity of crops. 


\section{DOI: $\underline{10.51386 / 25815946 / \mathrm{ijsms}-\mathrm{v} 4 \mathrm{i} 4 \mathrm{p} 112}$}

Volume: 4 Issue: 4

The form of agrosilvopasture applied by farmers is to mix several types of MPTS crops, forestry plants, and cattle under stands, and agricultural crops in the same land management unit. Agrosilvopasture is combining woody components (forestry) with agriculture and at the same time livestock or animals in the same land management unit [11]. Cattle is one of the main commodities cultivated by farmers in the West Halmahera Regency because it has a high selling value and is used as savings when farmers need money and have to sell it. Agrosilvopasture is an alternative method of land use to obtain both food and feed [12]. The results of the financial analysis of the application of the agrosilvopastoral farming system in Sumanik Village have a positive impact on the economy of the farming community [13].

Several types of commodities cultivated by farmers on each land are coconut, nutmeg, cocoa, cloves, a combination of several types of fruit crops such as jackfruit, langsat, mango, durian, rambutan, and other types of MPTS which are planted randomly in plots of land and crops. forestry such as teak, binuang, and others coconut and nutmeg are the primary plants on the island of Halmahera, including West Halmahera, and in their management, they are planted in intercropping with other crops, either planted randomly or in rows but they have the same spacing for each type of plant.

\section{B. Agroforestry Development Strategy with SWOT-AHP}

Agroforestry development strategies are analyzed using the SWOT and AHP formulations. The SWOT analysis starts with identifying and classifying various internal factors (strengths and weaknesses) and external factors (opportunities and threats) based on the conditions and problems in the research location. Identification of SWOT factors either through discussions with various parties and literature studies.

Next, it calculates the value of strengths, weaknesses, opportunities, and threats, continued to calculate the SWOT factor and to calculate the priority of the SWOT group by comparing internal factors (strengths and weaknesses) and external factors (opportunities and threats) so that they can formulate the priority value of agroforestry development strategies in West Halmahera Regency. 14].

\section{1) Internal and External Factors}

The factors which have been identified based on the SWOT group are then compiled into a questionnaire. The score given to each question is 1 to 5 and the respondents who were interviewed were 30 farmers. The values obtained are then added up and divided by the number of respondents to get the average score of each component. The identified internal (strengths and weaknesses) and external (opportunities and threats) factors are presented in Table 1 and Table 2

Table 1. Classification of internal factors

\begin{tabular}{clc}
\hline & \multicolumn{1}{c}{ Strengths } & Average Score \\
\hline S1 & The commodity being cultivated is a commodity that has a high selling value and & 4,40 \\
& has a good ecological function & 3,83 \\
S2 & Climate suitability that supports commodity growth & 3,97 \\
S3 & The workforce is dominated by productive age and has good work experience & 3,13 \\
S4 & Relatively low cost & 4,07 \\
S5 & Income from continuous farming & 3,60 \\
S6 & There is government support in the form of assistance, counseling, and assistance & 4,03 \\
S7 & Stable price & Average Score \\
\hline & \multicolumn{1}{c}{ Weaknesses } & 2,83 \\
\hline W1 & Commodity cultivated is low & 3,63 \\
W2 & Lack of community's insights to adjust the planting time, cropping patterns, use & 3,50 \\
& of fertilizers, proper use of pesticides, and prevention of pest and disease, & 3,33 \\
W3 & Low skill in farming & 3,80 \\
W4 & Sub-optimal land cultivation & Lack of programs or policies from the government in efforts to develop forestry \\
\end{tabular}


DOI: $\underline{10.51386 / 25815946 / \mathrm{ijsms}-\mathrm{v} 4 \mathrm{i} 4 \mathrm{p} 112}$

Volume: 4 Issue: 4

plant cultivation

W6 Availability and quality of farm roads that are still not supported

W7 The bargaining position of farmers with traders is low and prices are determined by traders or middlemen

Source: Data processed 2021

The results of the interview with respondents on the strength factor have the highest average score, namely 1) The commodity being cultivated is an excellent commodity and has a good ecological function; 2) Income from continuous farming is regularly and definitely; and 3) Stable prices. The weakness factors are 1) a lack of programs or policies from the government related to the development of forestry plants; 2) Availability and quality of farm roads that have not been supported; 3) The bargaining position of farmers against traders remains low.

On the opportunity factor which has the highest score, namely 1) Market demand continues to increase, especially for good commodities, 2) Availability of road and bridge infrastructure as well as supporting communication facilities, and 3) Ease of obtaining seeds from private gardens. Meanwhile, the threat factors are 1) market prices that tend to fluctuate; 2) quite a high pest and disease attacks; and 3) negative interactions among types of plants or commodities.

Table 2. Classification of external factors

\begin{tabular}{clc}
\hline & \multicolumn{1}{c}{ Opportunities } & Average score \\
\hline O1 & Relatively simple cultivation techniques & 3,73 \\
O2 & Adoption of farming practices from migrant farmers & 3,73 \\
O3 & Ease of getting seeds from private gardens & 4,23 \\
O4 & The cultivated land is very wide & 3,97 \\
O5 & The role of non-governmental organizations, the private sector, and entrepreneurs & 3,57 \\
& in supporting cooperation with farmers in the agricultural sector & \\
O5 & The role of non-governmental organizations, the private sector, and entrepreneurs & 3,57 \\
& in supporting cooperation with farmers in the agricultural sector & 4,40 \\
O7 & Market demand continues to increase & Threats \\
\hline & & Average Score \\
\hline T1 & A negative interaction occursamong the types of plants or commodities & 3,43 \\
T2 & The presence of pests and diseases on plants & 3,67 \\
T3 & Public interest in monoculture farming & 2,67 \\
T4 & The low willingness of farmers to access capital to develop agroforestry & 2,93 \\
T5 & The high cost of production, both production facilities, and labor hire & 3,00 \\
T6 & Market price fluctuation & 3,93 \\
\hline
\end{tabular}

Source: Data processed 2021

\section{2) Weighting,Consistency Ratio of SWOT and SWOT Factors}

The weight score for the SWOT group and SWOT factors can be seen in Table 3. The highest priority score for the SWOT group is a threat $(0.29)$ and the lowest value is in the opportunity group $(0.20)$. It means that it is important to make more use of the available opportunity factors to suppress high threat factors as high threat factors can hinder the development of agroforestry in the West Halmahera Regency.

Local priority is the eigenvector score of each element factor obtained from the average score of the pairwise combined matrix normalization. While the global priority is obtained from the local priority score multiplied by the group priority value. The global priority is to consider the overall score of each element in all SWOT groups. 


\section{DOI: $\underline{10.51386 / 25815946 / i j s m s-v 4 i 4 p 112}$}

Volume: 4 Issue: 4

July to August 2021

https://www.ijsmsjournal.org

In local priority for strength factor, the highest score is climate suitability supporting commodity growth (0.2082). Climatic conditions are influentially supportive of plant growth, in particular with leading commodities. The highest score on the weakness factor is the low commodity cultivated (0.2478). The low commodity cultivated is the lack of optimizing the land under the stand because of the high threat such as plants which are easily damaged by wild cattle.

Table 3. Group priority scores and SWOT factors

\begin{tabular}{|c|c|c|c|c|c|}
\hline Groups & Priority & Factor & $\begin{array}{c}\text { Consistency } \\
\text { Ratio }\end{array}$ & Local Priority & Global Priority \\
\hline \multirow{7}{*}{ Strengths } & \multirow{7}{*}{$0,24^{(3)}$} & $\mathrm{S} 1$ & \multirow{7}{*}{0,48} & $0,1328^{(4)}$ & $0,0323^{(16)}$ \\
\hline & & $\mathrm{S} 2$ & & $0,2082^{(1)}$ & $0,0506^{(5)}$ \\
\hline & & S3 & & $0,1508^{(3)}$ & $0,0366^{(11)}$ \\
\hline & & S4 & & $0,1573^{(2)}$ & $0,0382^{(10)}$ \\
\hline & & S5 & & $0,1228^{(6)}$ & $0,0298^{(18)}$ \\
\hline & & S6 & & $0,1240^{(5)}$ & $0,0301^{(17)}$ \\
\hline & & S7 & & $0,1041^{(7)}$ & $0,0253^{(23)}$ \\
\hline \multirow{7}{*}{ Weakness } & \multirow{7}{*}{$0,27^{(2)}$} & W1 & \multirow{7}{*}{0,34} & $0,2478^{(1)}$ & $0,0679^{(1)}$ \\
\hline & & W2 & & $0,1330^{(3)}$ & $0,0364^{(12)}$ \\
\hline & & W3 & & $0,0988^{(7)}$ & $0,0271^{(21)}$ \\
\hline & & W4 & & $0,1011^{(6)}$ & $0,0277^{(19)}$ \\
\hline & & W5 & & $0,1319^{(4)}$ & $0,0361^{(13)}$ \\
\hline & & W6 & & $0,1812^{(2)}$ & $0,0496^{(6)}$ \\
\hline & & W7 & & $0,1061^{(5)}$ & $0,0291^{(22)}$ \\
\hline \multirow{7}{*}{ Opportunity } & \multirow{7}{*}{$0,20^{(4)}$} & $\mathrm{O} 1$ & \multirow{7}{*}{0,32} & $0,1732^{(3)}$ & $0,0338^{(15)}$ \\
\hline & & $\mathrm{O} 2$ & & $0,1820^{(2)}$ & $0,0356^{(14)}$ \\
\hline & & $\mathrm{O} 3$ & & $0,1219^{(4)}$ & $0,0238^{(24)}$ \\
\hline & & O4 & & $0,1135^{(5)}$ & $0,0222^{(25)}$ \\
\hline & & O5 & & $0,2521^{(1)}$ & $0,0493^{(7)}$ \\
\hline & & O6 & & $0,1007^{(6)}$ & $0,0197^{(26)}$ \\
\hline & & $\mathrm{O} 7$ & & $0,0567^{(7)}$ & $0,0111^{(27)}$ \\
\hline \multirow{6}{*}{ Threats } & \multirow{6}{*}{$0,29^{(1)}$} & T1 & \multirow{6}{*}{0,40} & $0,2058^{(2)}$ & $0,0592^{(3)}$ \\
\hline & & $\mathrm{T} 2$ & & $0,1439^{(5)}$ & $0,0414^{(9)}$ \\
\hline & & T3 & & $0,1923^{(3)}$ & $0,0553^{(4)}$ \\
\hline & & $\mathrm{T} 4$ & & $0,2098^{(1)}$ & $0,0604^{(2)}$ \\
\hline & & T5 & & $0,1529^{(4)}$ & $0,0440^{(8)}$ \\
\hline & & T6 & & $0,0952^{(6)}$ & $0,0274^{(20)}$ \\
\hline
\end{tabular}

Source: Data processed 2021

In the table above, it can be seen that the Consistency Ratio (CR) score of the combined pairwise comparison matrix is all consistent, namely CR > 0-1. It refers to if the Consistency Ratio value < 0 , is considered an error, if $\mathrm{CR}=0$ is considered very consistent, if $\mathrm{CR}>0-1$ is considered consistent and if $\mathrm{CR}>1$, it is considered inconsistent. If the consistency ratio value is above 1.00, it means that it is inconsistent, it can be said that there is an error in the assessment test [15].

On the opportunity factor, the role of non-governmental organizations, the private sector, and entrepreneurs in supporting cooperation with farmers in the agricultural sector, occupies the highest priority value (0.2521). There are many traders, both small traders, and large traders, who build partners with farmers and are willing to lend money without interest. This can be used by farmers to develop agroforestry and repay loans using other agricultural products. While the threat factor is the low desire of farmers to access capital to develop agroforestry (0.2098). The mindset of the community is that the production age of the plant is quite long while the repayment 


\section{DOI: $\underline{10.51386 / 25815946 / \mathrm{ijsms}-\mathrm{v} 4 \mathrm{i} 4 \mathrm{p} 112}$}

Volume: 4 Issue: 4

of the loan and the interest must be every month. The results of research on the determinants of agricultural output in Nigeria, agriculture credit has positive and significant impact on agricultural output, is even one of the main determinants of agricultural output in Nigeria. Therefore, credit to the agricultural sector via the rural farmers should be encouraged [16]. Meanwhile, in the global priority, the three highest values in a row are low cultivated commodities (0.0679), low farmers' desire to access capital to develop agroforestry (0.0604), and negative interactions between plant species or commodities $(0.0592)$.

\section{Formulation of Strategy and Determining Alternative Agroforestry Development Strategies}

Based on the results of the SWOT analysis in Table 1 and Table 2, an agroforestry development strategy can be formulated using the three highest average scores for each SWOT factor, and the results are presented in Table 4.

Table 4. Formulation of agroforestry development strategy

\begin{tabular}{|c|c|c|}
\hline $\begin{array}{l}\text { Internal } \\
\text { Factor } \\
\text { External } \\
\text { Factor }\end{array}$ & $\begin{array}{c}\text { Strengths: } \\
\text { S1 } \\
\text { S5 } \\
\text { S7 }\end{array}$ & $\begin{array}{l}\text { Weakness: } \\
\text { W5 } \\
\text { W6 } \\
\text { W7 }\end{array}$ \\
\hline $\begin{array}{c}\text { Opportunity: } \\
\text { O3 } \\
\text { O6 } \\
\text { O7 }\end{array}$ & $\begin{array}{l}\text { SO Strategy } \\
\text { 1. Counseling and guidance regarding the } \\
\text { selection of superior seeds and tree plant } \\
\text { propagation techniques as well as } \\
\text { optimizing the use of land under stands } \\
\text { with monthly crop cultivation to increase } \\
\text { daily income and maintain environmental } \\
\text { balance by trees and other components (S1, } \\
\text { S5, O3); SO1 } \\
\text { 2. Improving the quality of infrastructure for } \\
\text { roads, bridges, and communication } \\
\text { networks for the convenience of } \\
\text { transporting agricultural products (S5, } \\
\text { O6); SO2 } \\
\text { 3. Developing partnership patterns between } \\
\text { farmers and entrepreneurs, especially for } \\
\text { superior commodities as markets (S7, O7); } \\
\text { SO3 }\end{array}$ & $\begin{array}{l}\text { WO Strategy } \\
\text { 1. Socialization by relevant agencies to } \\
\text { encourage the community to develop } \\
\text { forestry plant cultivation, for the } \\
\text { benefit of soil and water conservation, } \\
\text { as well as to take advantage of business } \\
\text { opportunities. For this reason, the } \\
\text { community needs to be assisted with } \\
\text { superior seeds (subsidies), in addition } \\
\text { to optimally utilizing the available } \\
\text { seeds on community land (W5, O3); } \\
\text { WO1 } \\
\text { 2. Utilization of village funds and the } \\
\text { convenience of public infrastructure as } \\
\text { well as community cooperation in } \\
\text { building farm road infrastructure (W6, } \\
\text { 06,); WO2 } \\
\text { 3. Improving the quality of agricultural } \\
\text { products and maintaining the } \\
\text { consistency of agricultural products, } \\
\text { especially superior commodities to } \\
\text { meet market demand (W7,O7); WO3 }\end{array}$ \\
\hline $\begin{array}{c}\text { Threats: } \\
\text { T1 } \\
\text { T2 } \\
\text { T6 }\end{array}$ & $\begin{array}{l}\text { ST Strategy } \\
\text { 1. Increasing education and training activities, } \\
\text { to develop public knowledge about good } \\
\text { cropping patterns, proper use of pesticides, } \\
\text { and pest and disease prevention in plants } \\
\text { (S1, T1, T2); ST1 } \\
\text { 2. Developing a partnership pattern for the } \\
\text { procurement of agricultural facilities and }\end{array}$ & $\begin{array}{l}\text { WT Strategy } \\
\text { 1. Increasing the intensity of counseling, } \\
\text { mentoring and coaching, by taking into } \\
\text { account the conditions and problems } \\
\text { faced by farmers in the field, (W5, } \\
\text { T1,T2); WT1 } \\
\text { 2. Affirmation of Government regulations } \\
\text { in protecting farmers' rights through } \\
\text { policies related to the price of each }\end{array}$ \\
\hline
\end{tabular}


DOI: $\underline{10.51386 / 25815946 / \mathrm{ijsms}-\mathrm{v} 4 \mathrm{i} 4 \mathrm{p} 112}$

Volume: 4 Issue: 4

\begin{tabular}{|l|l|l|}
\hline $\begin{array}{l}\text { infrastructure to support the enhancement } \\
\text { of agroforestry (S5, T2); ST2 }\end{array}$ & $\begin{array}{l}\text { commodity through the determination } \\
\text { of government purchase prices (HPP) } \\
\text { in an open and informed manner } \\
\text { through up-to-date mass media and } \\
\text { monitoring of traders or middlemen } \\
\text { (W6, W7,T6); WT2 }\end{array}$ \\
$\begin{array}{l}\text { 3. Combining more than one type of annual } \\
\text { crop to cover each other with commodity } \\
\text { prices fluctuating and continuing to replant } \\
\text { post-harvest on monthly crops (S5, S7, T6); } \\
\text { ST3 }\end{array}$ & $\begin{array}{l}\text { 3. Encouraging communities to take } \\
\text { advantage of the ease of borrowing } \\
\text { capital with low-interest rates as a } \\
\text { capital strengthening for developing } \\
\text { agroforestry (W7, T6); WT3 }\end{array}$ \\
\hline
\end{tabular}

Source: Data processed 2021

The strategies which have been formulated above are then analyzed using the AHP to gain choices with the highest priority score. The order or ranking of the strategic priority score can be seen in Table 5 .

Table 5. Values of weights and rankings of strategic priority values

\begin{tabular}{ccccccc}
\hline $\begin{array}{c}\text { SWOT } \\
\text { Formulation }\end{array}$ & Weight Score & Ranking & & $\begin{array}{c}\text { SWOT } \\
\text { Formulation }\end{array}$ & Weight Score & Ranking \\
\cline { 1 - 2 } \cline { 5 - 6 } SO1 & 0,316 & 7 & & WO1 & 0,506 & 1 \\
SO2 & 0,279 & 9 & & WO2 & 0,296 & 8 \\
SO3 & 0,404 & 4 & & WO3 & 0,198 & 12 \\
ST1 & 0,406 & 3 & & WT1 & 0,450 & 2 \\
ST2 & 0,259 & 10 & & WT2 & 0,212 & 11 \\
ST3 & 0,335 & 6 & & WT3 & 0,338 & 5 \\
\hline
\end{tabular}

Source: Data processed 2021

The results of the pairwise comparison analysis show that there are three alternative options with the highest value, namely 1) Socialization by relevant agencies to encourage the community to develop forestry plant cultivation, for the sake of soil and water conservation, and also as a business opportunity. In this regard, the community needs to be assisted with superior seeds (subsidies), in addition to optimally utilizing the available seeds on community land (0.506). The government must pay more attention to the development of forestry plant cultivation to prevent illegal logging due to the high demand for wood. This will result in flooding in the rainy season and a decrease in the volume of river water; 2) Increase the intensity of counseling, mentoring and coaching, by taking into account the conditions and problems faced by farmers in the field $(0.450)$. The importance of increasing the intensity of counseling and doing it regularly so that farmers can discuss and get solutions to the problems they face; 3) Increase education and training activities, to develop public knowledge about good cropping patterns, proper use of pesticides and pest and disease prevention in plants (0.406). Farmers need information about the types of pesticides and how to use them properly, as well as techniques for special treatment of seeds before planting to prevent crop failure due to plant pests and diseases.

\section{CONCLUSIONS}

1. Alternative strategies which can be offered are 1) Socialization by relevant agencies to encourage the community to develop forestry plant cultivation, for the benefit of soil and water conservation, and also to take advantage of business opportunities. For this reason, the community needs to be assisted with superior seeds (subsidies), in addition to optimally utilizing the available seeds on community land; 2) Increase the 


\section{DOI: $10.51386 / 25815946 / \mathrm{ijsms}-\mathrm{v} 4 \mathrm{i} 4 \mathrm{p} 112$}

Volume: 4 Issue: 4
July to August 2021

\section{https://www.ijsmsjournal.org}

intensity of counseling, mentoring and coaching, by taking into account the conditions and problems faced by farmers in the field; 3) Increase education and training activities, to develop public knowledge about good cropping patterns, proper use of pesticides and pest and disease prevention in plants.

2. The three alternatives above, in general, can be offered to overcome weaknesses and overcome threats, which are experienced in the development of Agroforestry in West Halmahera Regency, North Maluku, in the future.

\section{REFERENCES}

[1] Rianse, U. dan Abdi. 2010. Agroforestri Solusi Sosial dan Ekonomi Pengelolaan Sumber Daya Hutan. Alfabeta. Bandung.

[2] Tjatjo, Nurmasita T., M. B. dan H. U. (2015). Karakteristik Pola Agroforestri Mayarakat di Sekitar Hutan Desa Namo Kecamatan Kulawi Kabupaten Sigi. Jurnal Sains Dan Teknologi Tadulako, 4(3), 55-64.

[3] Mulyono, J., \& Munibah, K. (2016). Strategi Pembangunan Pertanian di Kabupaten Bantul dengan Pendekatan A’WOT. Pengkajian dan Pengembangan Teknologi Pertanian, 19(3), 199-211.

[4] BukharidanFebryano, I.G. (2010). Desain Agroforestry Pada Lahan Kritis (Studi Kasus Di Kecamatan Indrapuri Kabupaten Aceh Besar). Perennial, 6(1), 53-59. https://doi.org/10.24259/perennial.v6i1.198

[5] Indrianti, M. A., \& Ulfiasih. (2018). Implementasi Sistem Agroforestri sebagai Solusi Pertanian Berkelanjutan di Gorontalo. Seminar Nasional.

[6] Rohadi, D., Herawati, T., Firdaus, N., Maryani, R., \& Permadi, P. (2013). Strategi Nasional Penelitian Agroforestri.

[7] Amin, M., Rachman, I., \& Ramlah, S. (2016). Jenis Agroforestri dan Orientasi Pemanfaatan Lahan di Desa Simoro Kecamatan Gumbasa Kabupaten Sigi. Warta Rimba, 4(1), 97-104.

[8] Muryunika, R. (2015). Strategi Pengelolaan dan Pengembangan Agroforestri Berbasis Kelapa Sawit di Jambi. Tesis. IPB. Bogor.Bogor.

[9] Hidayat, M. (2020). "Strategi Pengelolaan KPHP Awota dan KPHL Unit XV Jeneberang II dengan Kombinasi Analisis Swot dan AHP. Tesis. Unhas.

[10] Lewerissa, E., Budiadi, Hardikusumo, S., \& Subejo. (2020). Penerapan Pola Agroforestri Berbasis Kelapa dan Pendapatan Petani di Desa Samuda, Kabupaten Halmahera Utara. Makila, 14(1), 1-14. https://doi.org/10.30598/makila.v14i1.2502

[11] Ma'ruf, A. (2017). Agrosilvopastura sebagai Sistem Pertanian Terencana Menuju Pertanian Berkelanjutan. Bernas, 13(1), 81-90. https://doi.org/10.31227/osf.io/295bk

[12] Suwignyo, B., Suryanto, P., Putra, E. T. S., Alam, T., \& Prianto, S. D. A. (2015). Potential of Corn as Forage on Alfisol and Vertisol Soil in Agrosilvopastural System with Kayuputih (Melaleuca leucadendron Linn). Journal of Agricultural Science, 7(11), $268-276$. https://doi.org/10.5539/jas.v7n11p268

[13] Adnani, I., Febriamansyah, R., Jamarun, N., \& Avenzora, R. (2018). Study of Development Planning and Development Agrosilvopastoral for the Improvement of Village Economy in West Sumatra: (Case of Sumanik Village in Tanah Datar District). International Journal of Agricultural Sciences, 2(1), 10-25. https://doi.org/10.25077/ijasc.2.1.10-25.2018

[14] Ningsih, A. S., Baharuddin dan Malamassam, D. (2021). Candlenut Business Development Strategy (Aleurites mollucana L.Wild) in KPHL Selayar. International Journal of Science and Management Studies (IJSMS), 4(3), 224-234. Doi:10.51386/25815946/ijsmsv4i3p121

[15] Saaty, T.L. 2008. Decision Making with theAnalytic Hierarchy Process.International Journal Services Sciences. I (1) 83-98.

[16] Omekwe, Paul S.O., Bosco, Ekpenyong I., Obayori, Bidemi J. "Determinants of Agricultural Output in Nigeria”.International Journal of Science and Management Studies. 1 (4) : 65 - 73. 2018.https://doi.org/10.51386/25815946/ijsms-v1i4p109 